\title{
9
}

\section{Basic Schools in Each and Every Parish: The School Act of 1842 and the Rise of Mass Schooling in Sweden}

\author{
Johannes Westberg
}

Resulting from a complicated political process initiated by a royal proposition on February 1, 1840, the Swedish school act of 1842 was issued on June 18, 1842, and signed by King Karl XIV Johan. ${ }^{1}$ This school act was subject to recurrent criticism, continuously revised by circulars and regulations, and was modified by two additional school acts in 1882 and 1897. Nevertheless, the school act of 1842 created the main structure for Sweden's primary school system (folkskoleväsende) that lasted through the nineteenth century and achieved high enrollment levels at the end of the century.

Since the school act of 1842 was the main piece of primary school legislation of nineteenth-century Sweden, this chapter will focus on this act and its preconditions, content, and consequences. It will show that the school act was the result of a lengthy political debate on popular

This work was supported by the Swedish Research Council under Grant 2016-05230.

J. Westberg $(\bowtie)$

School of Humanities, Education and Social Sciences,

Örebro University, Örebro, Sweden

e-mail: Johannes.westberg@oru.se

(C) The Author(s) 2019

195

J. Westberg et al. (eds.), School Acts and the Rise of Mass Schooling,

https://doi.org/10.1007/978-3-030-13570-6_9 
education, describe the school system that the school act designed, and discuss the effects of the act using both existing research on the topic and primary sources.

\section{Household Instruction and the Rise of Mass Schooling}

Prior to the school act, popular education in Sweden was organized through a system of household instruction (hemundervisning) based on the Church Law of 1686. In keeping with Martin Luther's perception of society, this law gave the head of the household the responsibility for educating children and servants. Instruction was largely performed by household members, with a focus on reading and catechetical knowledge. The main role of the clergy was to verify and register the level of knowledge via examinations held in the parishioners' homes. Although imposed from above by the Protestant Kingdom of Sweden, the reading campaign enacted through household instruction also served the individual need for literacy and catechism and matched the existing traditions of family prayer and village reading. Since a basic reading ability and understanding of the Bible was required to be confirmed, take communion and be married, there were certainly reasons for individuals to master these skills. ${ }^{2}$

The system of household instruction was a success: Estimates indicate that the Swedish population reached universal reading ability by 1800 . Nevertheless, there was a critical educational debate in the eighteenth century that targeted this system of popular education. According to critics, household instruction overly focused on simple mechanical reading ability, neglecting subjects such as writing, arithmetic, and history. There was also criticism of parents' inability or unwillingness to guarantee the level of knowledge that was expected. ${ }^{3}$

Steps were consequently taken to complement household instruction with schooling. In 1723, a royal decision stated that parents unable to tend to their children's educational needs were required to ensure that their children were educated by someone else. If the parents were too poor to see to this, the parishes were obliged to fund the children's 
education. In 1762, a royal resolution stated that parishes should provide their parishioners with a teacher when deemed necessary. In 1768, a circular required the county administration (länsstyrelsen) to investigate how school buildings could be built in each parish. ${ }^{4}$ In addition, public proposals for educational reform were formulated. In a memorial intended for the parliament of 1738, Professor Andreas Rydelius argued that each parish should have a school building. In 1742, the cathedral chapter of Lund filed a report that included a proposal for school regulation requiring parents to send their children to schoolmasters. In 1798, the Pro Fide et Christianismo Society proposed a school ordinance for parish schools. ${ }^{5}$

Although further investigations are required to estimate the impact of these proposals and the attempts to promote the establishment of schools, the number of city and parish schools increased during the second half of the eighteenth century. In addition to pressures from above, this was also a matter of popular demand. There are indications that the importance of literacy increased among farmers due to the administrative demands of the enclosure movement and the increasing commercialization of farming. ${ }^{6}$ Consequently, schools were established in the countryside, funded and organized by noblemen and parishioners. Nils Torpson's investigation, published in 1888, found that there were 165 permanent schools in Sweden in 1768. Of these, 75 were funded by donations from wealthy individuals, and 90 were initiated and run by parishioners. A significant number of these early schools were established in the diocese of Lund, in the southernmost part of Sweden. This was partly due to influence from Denmark, where popular education in the eighteenth century depended on schools, rather than home instruction. In 1812, 106 primary school teachers were listed in the diocese of Lund. ${ }^{7}$

During the early decades of the nineteenth century, the number of primary schools continued to increase. This trend was mainly the result of local initiatives by parishioners or wealthy individuals, but the expansion of schooling was also supported by the Society for the Promotion of Monitorial Education (Sällskapet för växelundervisningens befrämjande), founded in 1822. At that time, the society listed 35 monitorial 
schools, which rose to approximately 400 in $1839 .{ }^{8}$ Overall, the number of primary schools increased to approximately 1500 by 1839.9

This growth of schooling during the early nineteenth century was accompanied by a political debate on the Swedish educational system that drew on both the criticism of the state of popular education mentioned above and discontent with the organization of secondary education. ${ }^{10}$ The political issue of education was also affected by contemporary political changes. As a result of prolonged dissatisfaction with the Swedish political system and the unfortunate Finnish War of 1808-1809, resulting in the loss of Finland, King Gustav IV Adolf was forced to abdicate. Following these events, Sweden adopted a new constitution in 1809. Influenced by Montesquieu's political theory, this constitution divided the political power between the king (as the executive branch of government) and the parliament (Standsriksdagen), which was a diet comprising four estates (peasants, burghers, clergy, and nobility). ${ }^{11}$

As Daniel Tröhler noted, new constitutions tend to result in new school laws. ${ }^{12}$ In Sweden, the constitution of 1809 was followed by an educational debate. At the 1809 parliament, just a couple of weeks after the adoption of the constitution, Gustaf Abraham Silverstolpe argued that Sweden needed an educational system that suited the new constitution, protected the nation's newfound freedoms, and provided peasants (who held one-fourth of the political power in parliament) with a proper education. Similar arguments, which should not be misinterpreted as early arguments for comprehensive schools targeting all social classes, recurred in the following parliaments of the 1810s and early 1820s. A more general civic education of the population was presented as vital, not only to the new political system, but also to support Sweden's economic and cultural development. ${ }^{13}$

However, a school act was delayed until 1842 for several reasons. In part, this was caused by the inherent tensions between the estates of the parliament. At the parliament of 1823, for example, the clergy perceived the arguments for educational reforms merely as a critique of how they organized popular education. ${ }^{14}$ Another issue that caused delays was funding. At the parliament of 1840-1841, the nobility, the clergy, and the burghers approved a solution that placed the cost 
of the proposed primary school system on local communities, and consequently primarily on the shoulders of the landholding peasants. However, the wealthy farmers of the peasant estate questioned why they were asked to fund not only their own children's education but also those of the increasing landless population. Taking aim at the clergy and the nobility, the farmers of the peasant estate instead argued that the school system should be funded by the central government through cuts in the ecclesiastical and military budgets. ${ }^{15}$

Since Sweden was undecidedly Protestant (until 1860, the law required Swedish citizens to be members of the Swedish church), religious conflicts were not an important issue in the nineteenth-century national school politics: Only in the local implementation of the school act, disputes arose with, for example, members of Baptist congregations. Instead, the main ideological disagreement was between so-called liberals and conservatives, and their different views of society, religion, and education. The conservatives promoted a restrictive view of popular education, arguing that catechism and reading instruction were all that the population needed, while the liberal wing favored a more extensive popular education. From their point of view, introducing a primary school system was a mechanism to create virtuous national citizens. In this respect, disseminating religious knowledge and reading skills was not enough. For example, farmers required a broad education to develop the agrarian industry, prepare for positions at the municipal level, and discuss political issues on a national level. To free the population from superstition and ignorance, and promote the economic, political, and social development of the Swedish nation, a more extensive education was necessary. ${ }^{16}$

The school act of 1842 can also be understood in the context of the social and political conditions of the first decades of the nineteenth century. Because of the agrarian revolution, social differentiation in Swedish society was increasing. In 1750-1850, the population of farmers increased by $10 \%$, while the landless population more than quadrupled. ${ }^{17}$ The Swedish economy also developed somewhat unevenly. There were indications of increased social differentiation in the 1830s, including a somewhat declining living standard for the broader strata and a perception of economic crisis when the 1837 harvest was weak and the 
winter of $1837-1838$ was unusually difficult. ${ }^{18}$ The popular political culture in the first half of the nineteenth century also evoked riots and violent unrest. There were 20 riots from 1825 to 1844 , including the Rabulist riots (Crusenstolpe-kravallerna) in Stockholm during the summer of 1838 (Fig. 9.1). ${ }^{19}$

Against this background, popular education became part of the debate on the social question (sociala fragan), that is, the debate on the problems of society that included fears of social unrest and political revolt. ${ }^{20}$ In this context, mass education was perceived as a way of controlling and disciplining the growing underclass of landless agricultural workers, tenant farmers, and squatters. In addition, revolutionary sentiments in Europe created fears among the upper classes that Swedish

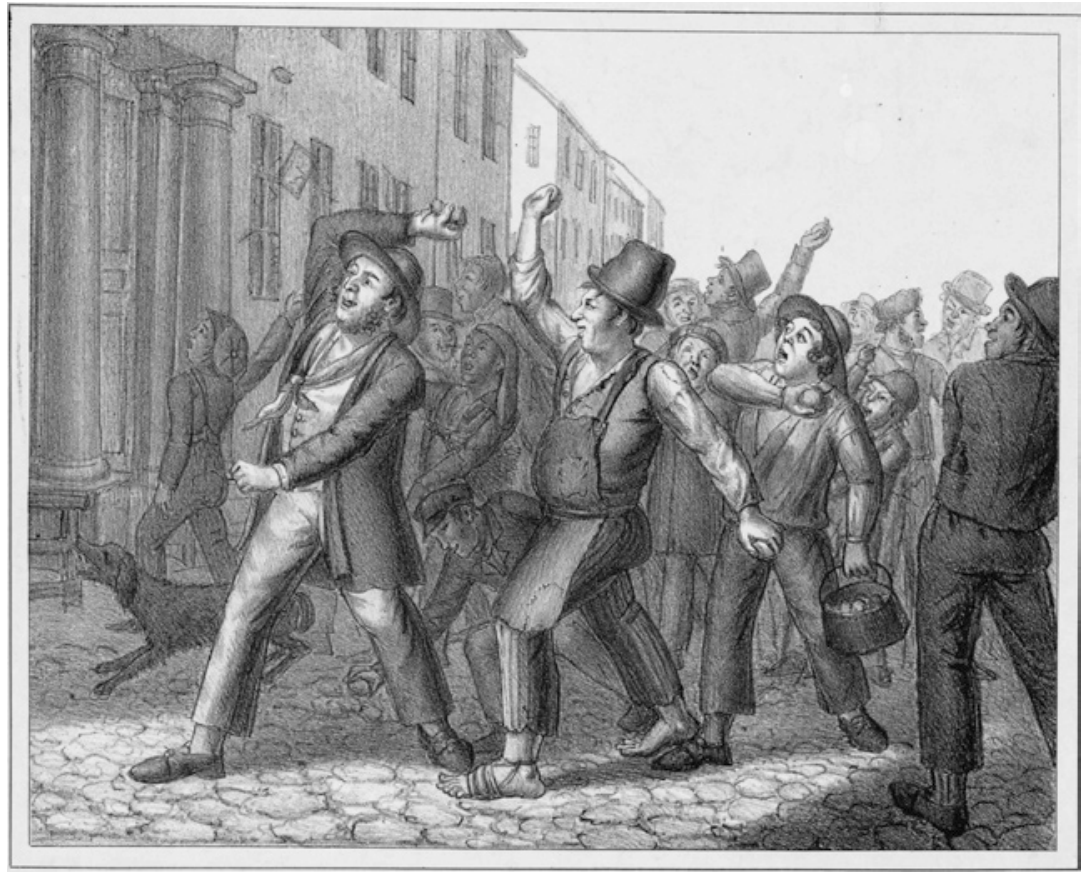

Fig. 9.1 "The attack on city hall." A portrayal of the Rabulist riots of the summer of 1838 (Sweden), probably by Ferdinand Tollin (1807-1860 or 1865) (Source Kungliga Biblioteket, kb-19728009) 
society could be turned on its head. Together with the introduction of solitary-confinement penitentiaries, poor relief, and Bible societies, primary schools were perceived as a social strategy to prevent crime, and curb immorality and potential rebellion, and instead foster a subservient and disciplined population. Arguing for the establishment of a primary school system, Swedish commentators referenced the US elite, and their belief in schooling as a safeguard against the raw masses. ${ }^{21}$ In this context, Lars Petterson described the school act of 1842 as a response to a moral panic and a fear of the dreaded underclass. ${ }^{22}$

\section{The Creation of a Decentralized School System}

The juridical discourse commonly makes a distinction between laws (made jointly by parliament and the government/head of state), and decrees and ordinances that the government/head of state can institute independently of the parliament. However, the Swedish Instrument of Government (1809) did not clearly distinguish between laws, statutes, and regulations. Instead, the term regulations (forfattning) was interpreted as synonymous with laws (lag). According to the Instrument, the Swedish king had the right to issue statutes and regulations on administrative and economic matters that, in effect, were laws which required general compliance. ${ }^{23}$

The Swedish school act of 1842 was a Kunglig stadga; that is, a royal statute or by-law issued by King Karl XIV Johan on June 18, 1842. In line with the Instrument of Government, this act was the result of a lengthy political process. On February 1, 1840, the king submitted a proposition to the four estates of the parliament. This proposition was first subject to comments by one of the parliament committees and then debated in the individual estates and parliamentary committees to reconcile differing opinions. As a result, the parliament submitted a revised proposal to the king on June 14, 1841, which he then remitted to the dioceses and counties for statements. On those grounds, he issued the Gracious Royal Statute on Popular Education in the Realm (Kongl. Maj:ts Nådiga Stadga angående folk-underwisningen i Riket) on June 18, 1842, countersigned by Professor of Ethics and Politics Samuel 
Grubbe, the acting head of the Ministry of Education and Ecclesiastical Affairs (Ecklesiastikdepartementet). ${ }^{24}$

The school act of 1842 was clearly inspired by an international educational debate and foreign examples. In the parliamentary debate of 1840-1841, Bishop C.A. Agardh argued that the school act should create a school system similar to that of Prussia and Saxony. The school organization of Württemberg was also a reference point when drafting the Swedish school act. The French philosopher and educationalist Victor Cousin's reports on schooling in Germany played a vital role in this respect. The Swedish school act was also influenced by its counterparts in Denmark (1814) and Norway (1827), and the knowledge gained from the organization of monitorial schools abroad. ${ }^{25}$

The school act of 1842 defined a decentralized national school system, based on the 2308 parishes of Sweden. The first paragraph presented the main layout of the system. It stated that at least one, preferably permanent school (folkskola) should be established in each urban and rural parish within five years. The school act allowed impoverished or sparsely inhabited parishes to organize a school that was shared by two or more parishes or establish an ambulatory school that traveled between villages. These ambulatory schools became a main feature of the Swedish school system. As late as $1900,22 \%$ of all primary schools were ambulatory. ${ }^{26}$

Starting in the 1850s, other types of schools were introduced, including those for the youngest school-aged children, remote areas, and higher primary schools intended for an advanced level of education for the laboring classes. While the former school types-the so-called smaiskolorna and mindre folkskolorna in the terminology of the renewed school act of 1882 — gained great popularity, the higher primary schools remained insignificant. Similarly, the organization of urban schools developed over time. Unlike the school acts of Denmark (1814), the Swedish school act of 1842 issued no specific regulations for urban schools. To address the challenges of Sweden's largest cities, specific school organizations were later implemented in Göteborg (1857), Stockholm (1861), and later in Malmö and Norrköping. ${ }^{27}$

To organize these schools, each parish (or sometimes more than one parish) constituted a school district (skol-district, spelled skoldistrikt 
in later school acts) managed by a school board (skol-styrelse, later termed skolrad). The school board, which comprised between five and 12 individuals according to the regulations of 1862, was led by the parish vicar or a priest acting in his place. The issue of teachers as members of the school board remained subject to debate throughout the second half of the nineteenth century. Some argued that such representation would be illegal, due to teachers being salaried by the school district. Eventually, teachers were formally given the right to meet with the school board once per year to discuss school matters through a school act amendment in 1892, later included in the revised version of the school act of $1897 .{ }^{28}$

The school act of 1842 stated that the school board was responsible for the schools in the school district. The school board should inspect schools and issue local regulations regarding instruction methods, disciplinary measures, and other school management and organization issues. ${ }^{29}$ The school board was placed under the governance of the parish meeting (sockenstämma), at which all taxable inhabitants of the parish had a vote. The parish meeting, led by the parish vicar, appointed and dismissed school board members, teachers and sextons, and was responsible for the school buildings and teachers' housing. The parish meeting also audited the school board's account books and had the final say in issues regarding school expenditures. ${ }^{30}$ As a result of this organization, the school act placed Swedish schools in the hands of the local community and more specifically in the hands of the influential strata of the community. ${ }^{31}$

In line with this decentralized organization, funding the Swedish school system was mainly the responsibility of the school districts. The school act of 1842 stated that the school districts were responsible for obtaining and maintaining premises for primary schools, and remunerating teachers. The school act suggested three sources of revenue for the school districts: A per capita tax, a general tax, and school fees. The latter was probably never an important revenue source and was abolished in $1883 .{ }^{32}$ A parish could also apply for funding from the central government, but only if it was too poor to fund teachers' salaries. ${ }^{33}$

As a result of this legislation, the Swedish school system remained decentralized in economic terms throughout the nineteenth century, even though state subsidies increased over time. Nevertheless, from 
1865 to 1900 , the central government contributed only $30 \%$ to the school districts' revenues, on average. However, after the state subsidy reform of 1913, state subsidies became the major source of funding for Swedish school districts. ${ }^{34}$

Fittingly for a largely rural society, the school funding system delineated by the school act of 1842 was based on both monetary and non-monetary items. The minimum wage consisted of 53 riksdaler banco, eight barrels of grains (at least half of which would be delivered in rye), decent housing, necessary fuel, a summer's grazing and winter fodder for a cow, and a land plot, if possible. Partly because the minimum salary set by the school act was clearly restricted, teachers commonly had various secondary occupations, in both the laborer and skilled sectors. In $1847,27 \%$ of all primary school teachers also worked as priests or sextons. By 1896, 57\% of rural teachers employed in folkskolor also earned revenues from secondary occupations. ${ }^{35}$

The school act stated that the funding of new school buildings should be based on the regulations for church buildings if no other arrangements were made. ${ }^{36}$ The regulations for church buildings are found in the Book of Building, included in the Civil Code of 1734 (1734 arrs lag). According to these regulations, building materials and transportation would be taxed according to land ownership, and work would be taxed according to households. This meant that landowning farmers would fund new schools by providing money or building materials, and that all inhabitants (both landowners and landless) would provide either labor or the funds to cover labor. ${ }^{37}$

Although the school act of 1842 largely placed the organizational and financial responsibilities of the school system in the hands of local school districts, the districts could not act entirely on their own. In addition to being governed by the regulations issued by the Ministry of Education and Ecclesiastical Affairs, the school districts were under the supervision of the bishop and cathedral chapters. Certain disagreements were resolved by the administrative board of each county (länsstyrelsen) or the district court (häradsrätten). Each year, the school districts were also required to present the cathedral chapter with a report on the state of their schools. Every third year, those reports were compiled and sent to the king. ${ }^{38}$ 
Over time, the central government's grip on the Swedish school tightened in some respects. In 1861, the first state school inspectors were installed, and school standards (normalplaner) were issued in 1878, 1889,1897 , and 1900. Those standards were a set of recommendations for a number of school types and curricula. To increase the quality of school buildings, Royal Building Plans (normalritningar) were issued in 1865 and $1878 .{ }^{39}$ Nevertheless, the power of the Swedish school system primarily remained in the hands of the school districts, in line with the formulations of the school act.

\section{The Content of Noncompulsory Schooling}

As the term folkskola suggests, the primary schools regulated by the school act of 1842 targeted das Volk, or the people. In this context, this was not a school intended for all Swedish people, but rather for the lower classes of society, the common people, or the working classes. In this respect, terms such as lower also carried a moral aspect. The term the people indicated not only the majority of the population and its poorer strata, but also an inferior and potentially dangerous class of society sometimes described in derogatory terms, such as raw, lazy, drunken, and uneducated..$^{40}$

Although the school act of 1842 stated that establishing schools was compulsory for parishes, the act did not make schooling compulsory for all school-aged children. Instead, the school act merely confirmed previous regulations stating that a basic education was compulsory, while schooling was not. The school act admittedly noted that all children should enroll in school, but specifically exempted children educated at home, and middle- and upper-middle-class children attending grammar schools (läroverk). In the former respect, the school act noted that home instruction would remain important in some areas. The school act also stated that children unable to attend school due to long, or seasonally impassable, routes to school were allowed to attend school only once or twice a week once they acquired the ability to read. ${ }^{41}$

In line with the school act's focus on the school districts' responsibility to establish schools, rather than on children's responsibility to attend 
school, the school act did not further define what schooling meant in terms of years or school days. The school act noted that children should start school by age 9 at the latest, but it did not define the age at which schooling should end or a standard number of school years. In fact, school age was first defined as from ages 7 to 14 in the revised school act of $1882 .{ }^{42}$ In practice, the most fitting definition of school-aged children in the early years of the school act was probably children from the ages of 7 to $13 .{ }^{43}$ The school year was also not defined by the act, even though the proposals that led to the school act suggested school years consisting of at least six or eight months. ${ }^{44}$ The school act was also vague with regard to gender. The act assumed that both boys and girls would attend school, and did not suggest separate schools. However, it stated that the school boards were responsible for implementing necessary differences between boys' and girls' education. ${ }^{45}$

Although the teaching profession in Sweden became feminized during the latter half of the nineteenth century, the teachers defined by the school act were men. ${ }^{46}$ The school act stated that teachers were required to have a degree from one of the teachers' colleges, to be established by each of Sweden's 12 cathedral chapters, or the normal school of the Society for the Promotion of Monitorial Education in Stockholm. The school act did not define the courses taught at these colleges but noted the level of knowledge required for a teacher. In addition to having a personality characterized by piety and moral conduct, teachers were required to have a complete mastery of reading and writing skills, and full knowledge of catechism, biblical history, natural history (naturlära), geography, and arithmetic. The teachers were also expected to be familiar with the methods of monitorial education and teaching gymnastics and psalm songs. ${ }^{47} \mathrm{~A}$ week at the Stockholm Teachers' College in 1848 (comprising 38 hours of class) consequently included $14 \mathrm{~h}$ of prayer and Bible studies, catechism, and Bible history. Five hours were spent on the Swedish language, four hours on singing instruction, three hours on geography and history, and two hours on arithmetic. $^{48}$

The content of teachers' instruction was related to conservative and liberal perceptions of education. On the one hand, the school act allowed a minimum curriculum for children who could not receive the 
complete primary school course, due to either poverty or lack of talent. This minimum amount of knowledge included instruction in reading, religious knowledge (catechism and biblical history), church singing (with the exception of those entirely lacking singing talent), writing, and arithmetic. The full curriculum also included geography, history, geometry, linear drawing, natural history, and physical education. ${ }^{49}$

The Swedish historiography of schooling has debated on how these two curricula should be understood. In addition to being interpreted as an outcome of the tension between conservative and liberal views of popular education, the school act has also been interpreted in terms of social control: The school act allowed for a basic education deemed appropriate for the knowledge that the people of the lower classes required. ${ }^{50} \mathrm{On}$ the other hand, the possibility of teaching a more comprehensive curriculum has been interpreted as an attempt to foster competent modern citizens. ${ }^{51}$ A third line of interpretation has acknowledged that the school act was promoted by landowning farmers, who favored a broader curriculum. ${ }^{52}$ These perceptions of the school act will be discussed below when the consequences of the school act are examined.

\section{One School Act, Varying Consequences}

The role of the school act of 1842 has been interpreted in various ways. In accordance with earlier traditions of educational history that emphasized political history, legislation and the efforts of great men, the school act has been described as a significant event that lay the foundation for compulsory schooling. ${ }^{53}$ Shifting the focus from politics to the broader social and cultural context, researchers have reduced the significance of the school act noting that the school act did not introduce literacy to the Swedish population, as the population already was able to read long before the school act. Without engaging in any encompassing studies of the school act's impact, researchers also noted that the act did not introduce schools, as half of the parishes already ran schools prior to the school act. ${ }^{54}$ On the basis of such observations, Petterson noted that the school act was merely a "belated official recognition and legitimization of an already existing practice." 55 
These varying perceptions of the school act highlight the importance of carefully defining exactly which consequences are under discussion. In studying the two decades after the school act of 1842, it is evident that the school act played different roles and had various implications. In terms of reception, the school act was far from a total success and faced significant criticism. During the parliament of 1844-1845, members testified to widespread popular resistance to schooling, and one of the members of the peasant estate even submitted a motion to repeal the school act, as requested by his electoral district. ${ }^{56}$ Some parishes in the dioceses of Växjö, Kalmar, and Gothenburg also demonstratively refused to obey the school act. ${ }^{57}$ The resistance against or indifference to schooling can also be observed at the local school district level, where school representatives lamented that only a few children attended school, or questioned the low attendance in periods of potato harvests. ${ }^{58}$

Despite these mixed reactions, the school act was followed by a marked expansion of the school system. The number of teachers increased from approximately 1500 in 1839 to 2785 in 1847 and 3458 in 1850 . Within a decade, the number of teachers more than doubled. Because schools during this period usually only had one teacher, the number of schools probably increased accordingly. ${ }^{59}$ This development meant that schools were established, not only in the previous strongholds such as Scania, but all over Sweden. When the five-year time limit expired in 1847, 188 schools had yet to be established, according to a report. In 1850, almost all parishes adhered to the requirements of the school act. In 1853, only a few parishes in Dalecarlia, the diocese of Gothenburg, and approximately 40 parishes in northern Sweden lacked a school system that fit the requirements of the school act of $1842 .^{60}$

The impact of the school act is perhaps most evident from a regional perspective. Prior to 1842 , primary schools were only found in some parts of the country. In 1839, almost half of Sweden's permanent schools (47\%) were located in the diocese of Lund, where only nine percent of the parishes lacked schools. In Stockholm city, all the parishes ran schools. However, schools were much less common in other areas. In the diocese of Skara, 88\% of the 236 parishes lacked schools. In the diocese of Härnösand, $83 \%$ of the parishes lacked schools, and 
$81 \%$ of the parishes in the diocese of Gothenburg also did not have schools. In total, $53 \%$ of all parishes lacked schools. ${ }^{61}$

As a consequence of the uneven distribution of schools prior to 1842, the impact of the school act varied. For regions that already had plenty of schools, their development following the school act of 1842 was less conspicuous. However, the impact of the school act was more obvious in the regions that lacked schools, which is also indicated by available statistical compilations from 1839 to $1862 .{ }^{62}$ Despite the shortcomings of such a periodization, a comparison shows striking regional variations in the number of permanent and ambulatory schools.

As Fig. 9.2 shows, both the diocese of Lund and the city of Stockholm were characterized by striking continuity. In 1839-1862, the number of schools increased from 40 to 44 in Stockholm and from

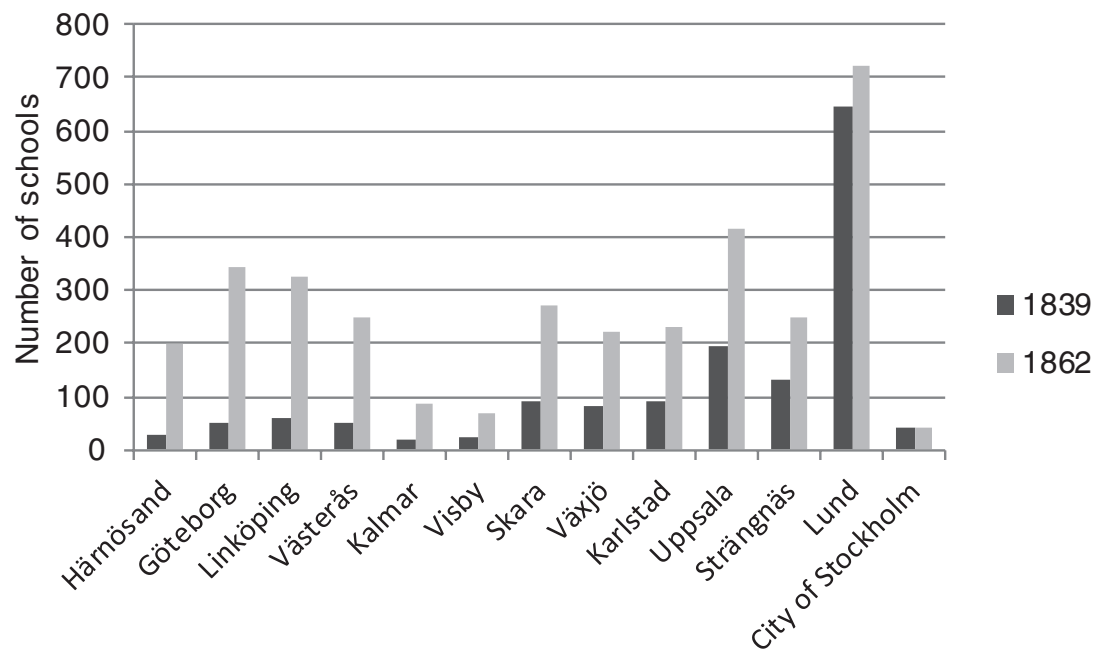

Fig. 9.2 The development of permanent and ambulatory schools in Sweden, 1839-1862 (Source "Kungl. Maj:ts Nådiga Proposition, No. 7" (1840-1841): Bilaga [1]; Statistisk sammanställning 1865, H3abe:1, Statistiska avdelningen, ED, RA; Paulsson, Historik öfver folkunderwisningen i Sverige från äldsta till närvarande tid, 434. Note The data on ambulatory schools in 1839 is based on the number of ambulatory teachers. Regarding the city of Stockholm, the data from 1862 pertains to 1865 . Please note that only folkskolor ("egentliga skolor") are included in this figure) 
647 to 721 in Lund diocese. In other areas, the growth was much more rapid. In the 161 parishes of the diocese of Härnösand, the number of permanent and ambulatory schools increased more than sevenfold from 28 to 201. Growth was also remarkable in Göteborg, Linköping, Västerås, and Kalmar, which had between four and six times as many schools in 1862, as in 1839.

There is, however, an important distinction between schools and school attendance. Although the school act of 1842 meant that all parishes had established schools by the 1850 s, this did not imply that all children had to attend school. However, this is not unexpected, as the school act made schools compulsory, but not schooling. The exact enrollment levels are obviously difficult to determine in a system that initially did not record the age of schoolchildren. Consequently, enrollment levels varied depending on if official statistics on the enrollment of children between the ages of 7 and 14 are used, or if school-aged children are defined as being between 7 and 13 years of age. The latter is likely a more accurate definition of school-aged children in the mid-nineteenth century. ${ }^{63}$

Regardless of the method of measurement, enrollment did not reach the same levels as the percentages of parishes with schools. In $1847,51 \%$ of school-aged children between 7 and 14 years of age were enrolled in primary schools. In 1868, this figure was $77 \%$, if so-called junior primary schools (småskolor) are included. ${ }^{64}$ If the school age is delimited to ages 7-13, the enrollment levels increase to $57 \%$ in 1847 and $83 \%$ in $1868 .{ }^{65}$ The initially low enrollment levels had many different causes. State school inspectors' reports noted long distances, parental negligence, "natural idiosyncrasies," caring for younger siblings, and herding as reasons why children stayed home from school. ${ }^{66}$ Studies have also shown that absence was clearly correlated with schoolchildren's distance to school, and to a lesser extent with social class. ${ }^{67}$

Although the school act of 1842 probably provided an important stimulus to the growth of mass schooling, neither the school act nor the Swedish central government should be perceived as the prime mover of mass schooling in Sweden. A thorough explanation of the expansion of this decentralized school system may instead include several factors promoting schooling at the local level, where schools were largely funded 
and organized. These include strong support for a basic education among various strata of society, teachers' livelihood diversification, and the financial and organizational powers of the Swedish parishes. ${ }^{68} \mathrm{With}$ their medieval origins and responsibilities for maintaining churches and remunerating the clergy, the parishes had both legitimacy and the ability to organize school districts and raise the necessary resources to fund schooling. In this context, the Swedish school districts' ability to tax their inhabitants both in monies and in kind, and to use the credit market for investments in school buildings, was particularly important. Rather than being merely a part of a state formation process, the expansion of the Swedish primary school system may instead be the result of the economic, organizational, and political formation of the Swedish parishes. ${ }^{69}$

\section{A Limited and Basic Education}

Although the school act of 1842 was followed by increases in enrollment and the number of schools, schoolchildren only received a limited education. In 1868, the average actual school year was only 34 weeks, consisting of 89 school days. The attendance of enrolled children was estimated at $43 \%$. Public statistics indicate that $36 \%$ of the schoolchildren at permanent primary schools attended school less than 60 days per year in 1868. In the region of Medelpad (Härnösand diocese), the number of school weeks varied between 20 and 31 in $1865 .^{70}$

The content of schoolchildren's education was consequently limited, with a strong focus on reading and arithmetic. During the first 20 years of the school act, schoolchildren mainly received a minimum education that included reading, catechesis, biblical history, writing, and arithmetic. In 1847 , only an estimated $6 \%$ of the children were given education above this minimum, which only rose to $7 \%$ in $1859 .{ }^{71}$ Figure 9.3 shows the percentage of schoolchildren taught in various school subjects in the early 1860 s. In addition to reading, most children were taught the catechesis (88\%), followed by writing (72\%), biblical history $(52 \%)$ and math (49\%), according to school inspectors' reports. 


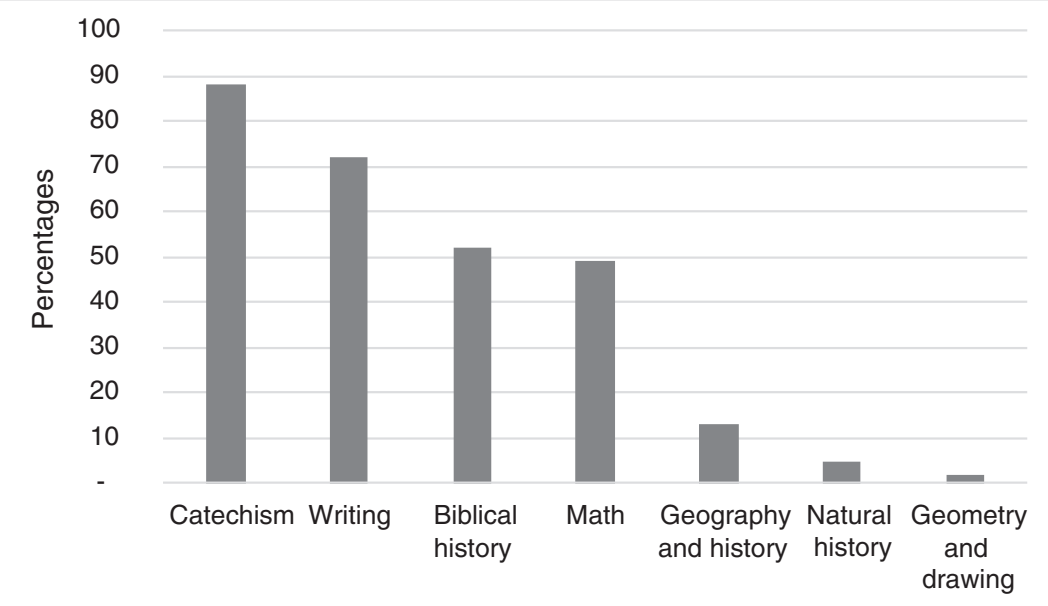

Fig. 9.3 School subjects taught from 1861 to 1863 (percentages of schoolchildren) in Sweden (Source Johansson, Kunskapskraven i den framväxande folkskolan, 154. Note The percentages are based on the 137,438 children present for school inspections from 1861 to 1863 . There were approximately 600,000 schoolchildren during this period. Reading instruction, which was a self-evident element of schooling, was not included in this investigation)

Comparatively, few children received education in subjects such as geography, history, natural history, and geometry. ${ }^{72}$

To remedy this focus on reading and catechesis, the Ministry of Education and Ecclesiastical Affairs issued an ordinance in 1864 urging schools to teach biblical history prior to catechism, to introduce writing and arithmetic early on, and not postpone the other subjects. ${ }^{73}$ As Figure 9.4 shows, unpublished statistics from 1865 nevertheless indicate that the curriculum remained rather narrow. Apart from reading, the main subjects taught in Swedish primary school were writing, biblical history, and catechism.

Unsurprisingly, the output of schooling, in terms of knowledge levels, was varied and often limited. According to a school inspector, the knowledge children actually received was difficult to determine because no final exam was required, and most children left school at an arbitrarily chosen date. ${ }^{74}$ In 1865 , no more than one-tenth of the 


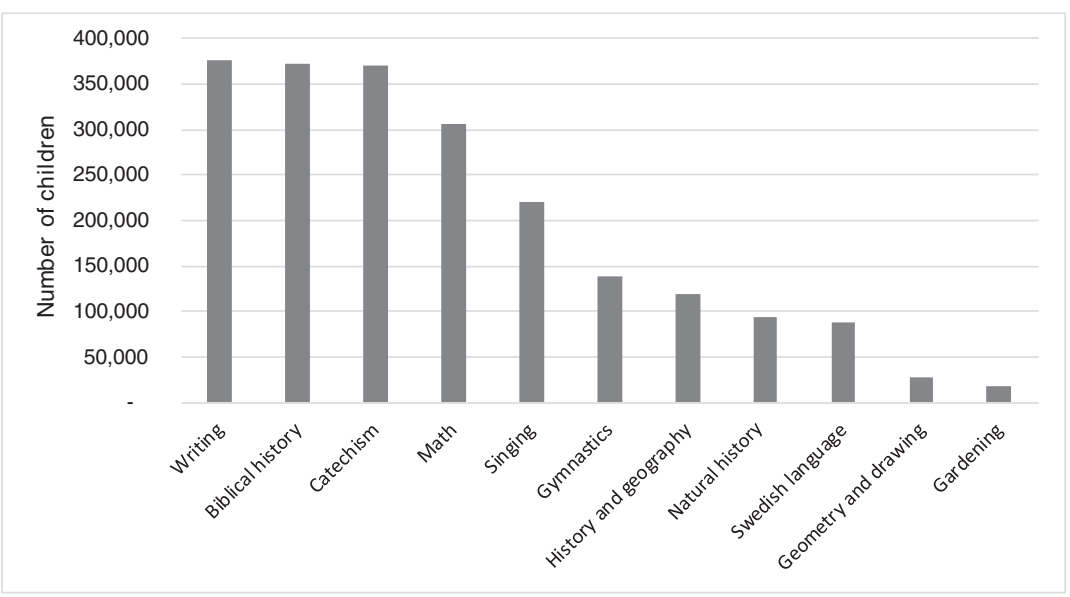

Fig. 9.4 School subjects taught in 1865 (number of children) in Sweden (Source Statistiskt sammandrag 1865, Stat. Avd., H3bb:1, ED, RA. Reading instruction was not included in this investigation. Note The subject of Swedish language included grammar, writing after dictation, and composing letters or short stories)

schoolchildren concluded their schooling with an examination. ${ }^{75}$ There are, however, reasons to believe that the output was limited, and that the school act of 1842 even may have caused a decrease in knowledge levels in the short run since it replaced the comparatively well-functioning system of household instruction. ${ }^{76}$ There also seems to have been differences pertaining to social class. Schoolchildren from the more prosperous strata of the rural population were more successful in church examinations (husförhör) than children from lower strata. ${ }^{77}$

The consequences of schooling on literacy during the second half of the century are nevertheless evident. The Swedish population was already literate by 1800 , due to the system of home instruction, yet schooling made the Swedish population also able to write by 1900 . By $1905,95 \%$ of convicts could both read and write, and $69 \%$ of military recruits had writing skills deemed acceptable, and 30\% of the recruits were even categorized as "good" in this respect. ${ }^{78}$

Although this limited education may be interpreted as a result of a conservative vision of schooling, or the ruling classes' interest in upholding the social order in a protestant nation state, it was also a 
result of local communities' interest in a basic schooling that neither demanded too much resources from the parish, nor was too timeconsuming for their children. State school inspectors frequently reported that parents preferred that their children not learn anything other than reading and the catechism; lamented that parents placed particular emphasis on memorizing the catechesis; complained that parents took children away from school once they had learned the catechesis; and expressed indifference to, or even dislike of, any teaching beyond reading and the catechesis. Parents also considered writing and math to be not particularly important, and banned girls from attending physical education classes because they considered such classes to be indecent. ${ }^{79}$ In this respect, the narrow curricula in the primary schools, following the school act of 1842, were also the result of parental demand. While created to promote the interests of a protestant nation state, the school act was made possible by the organizational and fiscal strength of the local school districts and implemented in a fashion that promoted the interests of parents and the local community.

\section{Notes}

1. Warne, Om tillkomsten av vår första folkskolestadga, 165.

2. Johansson, "History of Literacy in Sweden," 29-43; Lindmark, "Swedish History of Literacy," 100-4.

3. Lindmark, "Swedish History of Literacy," 102; Lindmark, "Hemundervisning och läskunnighet," 68-70.

4. Rodhe and Warne, Svenska folkskolans historia I, 361, 389; Lindmark, "Hemundervisning och läskunnighet," 72.

5. Rodhe and Warne, Svenska folkskolans historia I, 307, 319, 494-96.

6. Nilsson, Pettersson, and Svensson, "Agrarian Transition and Literacy: The Case of Nineteenth Century Sweden," 76-96.

7. Boli, New Citizens for a New Society, 222; Klose, Folkundervisningens finansiering, 96. See also Larsen's chapter on the Danish school laws of 1814.

8. Larsson, En lycklig mechanism, 33, 36.

9. Westberg, Funding the Rise of Mass Schooling, 139.

10. Lindmark, ed., 1812 års uppfostringskommittés enkät, iii. 
11. Rönström, "Forskardebatten kring 1809 års regeringsform," 450-51.

12. Tröhler, "Curriculum History or the Educational Construction of Europe in the Long Nineteenth Century," 285-87.

13. Thunander, Fattigskola - medborgarskola, 92-110.

14. Wennås, "Ideér och intressen," 47.

15. Westberg, "“Freedom for All! Injustice for None!" 223-27. See also Linge, Hur den svenska folkskolan kom till, 14.

16. See, e.g., Boli, New Citizens for a New Society, 215; Linge, Hur den svenska folkskolan kom till, 12-13. See also Edgren, "Nationen mot korporationen," 69-88.

17. Magnusson, Sveriges ekonomiska historia, 211.

18. Boli, New Citizens for a New Society, 217; Schön, En modern svensk ekonomisk historia, 69-73.

19. Olofsson, "Upploppskulturer," tab. 2; Berglund, "Soldater och stadsbor i förindustriellt gatuvåld," 25.

20. Petersson, "Den farliga underklassen," 26-27.

21. Boli, New Citizens for a New Society, 216-18; Lundgren, Den isolerade medborgaren: Liberalt styre och uppkomsten av det sociala vid 1800-talets mitt, 9-12, 31-33; Petterson, Frihet, jämlikhet, egendom och Bentham, 313; Rappe, "Från katekes till social fostran," 12.

22. Petterson, Frihet, jämlikhet, egendom och Bentham, 187.

23. Lagerroth, "Lagstiftningsmakten i 1809 års Rf," 234-36; Rönström, "Forskardebatten kring 1809 års regeringsform," 450.

24. Warne, Om tillkomsten av vår första folkskolestadga, 165.

25. Sjöstrand, Pedagogikens historia III:2, 127; Aquilonius, Folkskolans historia II, 319; Warne, Om tillkomsten av vår första folkskolestadga, 132; Wallner, Folkskolans organisation och förvaltning, 2.

26. SFS 1842:19 \$1; BiSOS P (1900), tab. 2.

27. Aquilonius, Folkskolans historia II, 44-54; Wallner, Folkskolans organisation och forvaltning, 30-42; SFS 1858:31.

28. SFS 1842:19 $₫ 2$; SFS 1862:15 $₫ 23$; SFS 1897:108 $₫ 8$; Sörensen, Svenska folkskolans historia III, 42-43.

29. SFS 1842:19\$2-3.

30. SFS 1843:27. See also Nydahl, I fyrkens tid, 16-17.

31. Westberg, Att bygga ett skolväsende, 135-43. The political and economic culture of this school organization is investigated in Westberg, "A Conflicted Political Will to Levy Local Taxes," and Westberg, Funding the Rise of Mass Schooling, chs. 2-3. 
32. Westberg, Funding the Rise of Mass Schooling, 116.

33. SFS 1842:19 \$3-4.

34. Westberg, Funding the Rise of Mass Schooling, 147-48.

35. SFS 1842:19 \$ 6; Aquilonius, Svenska folkskolans historia II, 419; Westberg, "How Did Teachers Make a Living?," 36.

36. SFS 1842:19 \$3-4.

37. Byggningabalken, 26 kapitlet $1 \$$, in Backman, Ny lag-samling. H. 1; SFS 1842:19 \$3; Wallner, Folkskolans organisation och förvaltning, 131.

38. Tegborg, Folkskolans sekularisering 1895-1909, 18-19; Wallner, Folkskolans organisation och förvaltning, 28-29; Westberg, Att bygga ett skolväsende, 138.

39. Westberg, Funding the Rise of Mass Schooling, 14-15.

40. Petterson, Frihet, jämlikhet, egendom och Bentham, 20-21; SAOB "Folk."

41. SFS $1842 \$ 8-9$.

42. SFS 1842:19 \$8; SFS 1882:8 \$35.

43. Johansson, En studie med kvantitativa metoder av folkundervisningen $i$ Bygdeå, 145.

44. Wallner, Folkskolans organisation och förvaltning, 65.

45. SFS 1842:19\$7.

46. Regarding feminization of the teaching profession, see Florin, "Social Closure as a Professional Strategy," 17-26.

47. SFS 1842:19\$6.

48. Sörensen, Växelundervisningssällskapets normalskola och folkskoleseminariet $i$ Stockholm, 49.

49. SFS 1842:19 \$5, 7.

50. See, e.g., Isling, Det pedagogiska arvet, 584.

51. Boli, New Citizens for a New Society, 236.

52. Lindmark, "Kunskapskraven i den framväxande folkskolan," 108; Thunander, Fattigskola - medborgarskola, 237.

53. Klose, Folkundervisningens finansiering, 223; Wallin, "Att forma en skolform," 375; Richardson, Ett folk börjar skolan, 7.

54. Johansson, En studie med kvantitativa metoder av folkundervisningen $i$ Bygdeå, 242-44; Petterson, "1842, 1822 eller 1882?” 22.

55. Petterson, "1842, 1822 eller 1882?” 27.

56. Aquilonius, Svenska folkskolans historia II, 332; Christensen, "Radikalism som strategi," 737.

57. Wallner, Folkskolans organisation och förvaltning, 7. 
58. Parish minutes, December 7, 1851, K1:3, Timrå ka, HLA; Parish minutes, August 8, 1853, K1:6, Tuna ka, HLA.

59. Berättelse om hwad $i$ Riket och dess Styrelse sig tilldragit sedan sista Riksdag 1856-1858, 85. See also Paulsson, Historik öfver folkunderwisningen, 432.

60. Wallner, Folkskolans organisation och förvaltning, 7-13.

61. Kungl. Maj:ts Nådiga Proposition, no. 7 (1840-1841), Appendix.

62. Although data were continuously collected by the Ministry of Education and Ecclesiastical Affairs, the ministry could not afford to make statistical compilations from 1840 to 1861.

63. Johansson, En studie med kvantitativa metoder av folkundervisningen $i$ Bygdeå, 145.

64. BiSOS P (1868), 22-23; En studie med kvantitativa metoder av folkundervisningen i Bygdeå, app. 11:2.

65. Johansson, The History of Literacy in Sweden, app. 1.

66. See, e.g., Berättelse om Folkskolorna inom Upsala Erkestift åren 18611863: Gestrikland och Helsingland, 18.

67. Boli, New Citizens for a New Society, 233-34; Uppgifter angående folkundervisningen i Medelpad 1865, H3abd:1, ED, RA.

68. Westberg, "How Did Teachers Make a Living?"; Andersson and Berger,"Elites and the Expansion of Education"; Westberg, "A Conflicted Political Will."

69. Westberg, Att bygga ett skolväsende, ch. 5, 9; Westberg, Funding the Rise of Mass Schooling, ch. 4-7.

70. Ljungberg and Nilsson, "Human Capital and Economic Growth," 80; Uppgifter ang. Folkundervisningen inom [...] Medelpads kontrakt för år 1865, Stat. avd., H3abd:1, ED, RA; BiSOS P (1868), 22-23.

71. Aquilonius, Svenska folkskolans historia II, 419.

72. Johansson, "Kunskapskraven i den framväxande folkskolan," 153-55.

73. "Royal Circular of April 22, 1864," in Folkskolestadgan med flera författningar rörande folkundervisningen, 26; BiSOS P (1868), xiv.

74. Berättelse om Folkskolorna inom Upsala Erkestift åren 1861-1863: Upland, 5.

75. Statistiskt sammandrag 1865, H3bb:1, ED, RA.

76. Johansson, En studie med kvantitativa metoder av folkundervisningen $i$ Bygdeå, 243-44.

77. Johansson, En studie med kvantitativa metoder av folkundervisningen $i$ Bygdeå, 207. 
78. Johansson, The History of Literacy in Sweden, 60, 89, 91.

79. Berättelse om Folkskolorna inom Upsala Erkestift åren 1861-1863: Upland, 4, 6; Berättelse om folkskolorna inom Linköpings stift åren 1861-1863, 22, 27; Berättelse om Folkskolorna inom Skara Stift åren 1861-1863, 47; Berättelse om Folkskolorna inom Strengnäs stift åren 1861-1863, 88; Berättelse om Folkskolorna inom Westerås stift åren 1861-1863, 23; Berättelse om Folkskolorna inom Skara stift åren $1869-1871,35$.

\section{References}

Andersson, Jens, and Thor Berger. "Elites and the Expansion of Education in Nineteenth-Century Sweden." The Economic History Review (Published Online). https://doi.org/10.1111/ehr.12738.

Aquilonius, Klas. Svenska folkskolans historia: Del II. Det svenska folkundervisningsväsendet 1809-1860. Stockholm: Albert Bonniers förlag, 1942.

Backman, Johan Harder. Ny lag-samling. H. 1, Innehållande de fyra förste balkarne af 1734 års lag. Örebro: s.n., 1831.

Berglund, Mats. "Soldater och stadsbor i förindustriellt gatuvåld: Stockholm, 1719-1848." In Sammanflätat: Civilt och militärt i det tidigmoderna Sverige, edited by Maria Sjöberg, 15-28. Uppsala: Swedish Science Press, 2009.

BiSOS P. (1868-1900). Bidrag till Sveriges officiella statistik. Undervisningsväsendet. Stockholm.

Boli, John. New Citizens for a New Society: The Institutional Origins of Mass Schooling in Sweden. Oxford: Pergamon, 1989.

Christensen, Jan. "Radikalism som strategi: Bondepolitik vid 1800-talets mitt." Historisk tidskrift 126, no. 4 (2006): 727-48.

Edgren, Henrik. "Nationen mot korporationen: Presspolitisk kamp om utbildning, samhälle och nationsbygge under 1810- och 1820-talen." In Det mångsidiga verktyget: Elva utbildningshistoriska uppsatser, edited by Anne Berg and Hanna Enefalk, 69-88. Uppsala: Swedish Science Press, 2009.

Florin, Christina. "Social Closure as a Professional Strategy: Male and Female Teachers from Co-operation to Conflict in Sweden, 1860-1906." History of Education 20, no. 1 (1991): 17-26.

Folkskolestadgan med flera författningar rörande folkundervisningen. Till ledning för skolråden. Stockholm: Norstedt, 1880.

Isling, Åke. Det pedagogiska arvet: Kampen för och mot en demokratisk skola del 2. Stockholm: Sober förlag, 1988. 
Johansson, Egil. En studie med kvantitativa metoder av folkundervisningen $i$ Bygdeå socken 1845-1873. Umeå: Umeå University, 1972.

. The History of Literacy in Sweden: In Comparison with Some Other Countries. Educational Reports. Umeå: Umeå University, 1977.

—. "Staten och skolan vid 1800-talets mitt: Ett lokalt och mer nyanserat perspektiv." In Utbildningshistoria 1992, edited by Egil Johansson and Stig G. Nordström, 145-60. Uppsala: Föreningen för svensk undervisningshistoria, 1992.

. "The History of Literacy in Sweden." In Understanding Literacy in Its Historical Contexts: Socio-Cultural History and the Legacy of Egil Johansson, edited by Harvey J. Graff, Alison Mackinnon, Bengt Sandin, and Ian Winchester, 28-59. Lund: Nordic Academic Press, 2009.

Klose, Gunilla. Folkundervisningens finansiering före 1842. Uppsala: Uppsala University, 2011.

Lagerroth, Fredrik. "Lagstiftningsmakten i 1809 års Rf: En rättshistorisk undersökning." Statsvetenskaplig tidskrift 43, no. 3-4 (1940): 194-247.

Larsson, Esbjörn. En lycklig mechanism: Olika aspekter av växelundervisningens som en del av 1800-talets utbildningsrevolution. Uppsala: Swedish Science Press, 2014.

Lindmark, Daniel, ed. 1812 års uppfostringskommittés enkät: Svaren från landsförsamlingarna i Medelpad. Umeå: Forskningsarkivet, 1987.

- "Kunskapskraven i den framväxande folkskolan." In Utbildningshistoria 1992, edited by Egil Johansson and Stig G. Nordström, 77-116. Uppsala: Föreningen för svensk undervisningshistoria, 1992.

- "Universalism in the Swedish History of Literacy." In Understanding Literacy in Its Historical Contexts: Socio-Cultural History and the Legacy of Egil Johansson, edited by Harvey J. Graff, Alison Mackinnon, Bengt Sandin, and Ian Winchester, 99-119. Lund: Nordic Academic Press, 2009.

—. "Hemundervisning och läskunnighet." In Utbildningshistoria: En introduktion, edited by Esbjörn Larsson and Johannes Westberg, 61-73. Lund: Studentlitteratur, 2011.

Linge, Karl. Hur den svenska folkskolan kom till: Striderna inom och utom riksdagen. Stockholm: Albert Bonnier, 1911.

Ljungberg, Jonas, and Anders Nilsson. "Human Capital and Economic Growth: Sweden 1870-2000.” Cliometrica 3, no. 1 (2009): 71-95.

Lundgren, Frans. Den isolerade medborgaren: Liberalt styre och uppkomsten av det sociala vid 1800-talets mitt. Hedemora: Gidlund, 2003.

Magnusson, Lars. Sveriges ekonomiska historia. Stockholm: Prisma, 2002. 
Nilsson, Anders, Lars Pettersson, and Patrick Svensson. "Agrarian Transition and Literacy: The Case of Nineteenth Century Sweden." European Review of Economic History 3, no. 1 (1999): 76-96.

Nydahl, Erik. I fyrkens tid: Politisk kultur i två ångermanländska landskommuner 1860-1930. Sundsvall: Mid Sweden University, 2010.

Olofsson, Magnus. "Upploppskulturer: Stockholm och landsort i svenska 1800-talsupplopp." Arbetarhistoria 149-150, no. 1-2 (2014): 13-17.

Paulsson, Per. Historik öfver folkunderwisningen i Sverige från äldsta till närvarande tid. Stockholm: Adolf Bonnier, 1866.

Petersson, Birgit. "Den farliga underklassen": Studier i fattigdom och brottslighet $i$ 1800-talets Sverige. Umeå: Almqvist \& Wiksell International, 1983.

Petterson, Lars. "1842, 1822 eller 1882? Vad är det som bör firas?”. Forskning om utbildning. Tidskrift för analys och debatt 18, no. 4 (1991): 22-27.

- Frihet, jämlikhet, egendom och Bentham: Utvecklingslinjer $i$ svensk folkundervisning mellan feodalism och kapitalism, 1809-1860. Uppsala: Almqvist \& Wiksell International, 1992.

Rappe, Ewa. "Från katekes till social fostran." Häften för kritiska studier 6, no. 5-6 (1973): 6-32.

Richardson, Gunnar. Ett folk börjar skolan: Folkskolan 150 àr 1842-1992. Stockholm: Allmänna förlaget, 1992.

Rodhe, Edvard, and Albin Warne. Svenska folkskolans historia: Del I. Stockholm: Albert Bonniers förlag, 1940.

Rönström, Emma. "Forskardebatten kring 1809 års regeringsform -Till frågan om grundlagens härkomst." Statsvetenskaplig tidskrift 100, no. 4 (1997): 448-67.

Schön, Lennart. En modern svensk ekonomisk historia: Tillväxt och omvandling under två sekel. Stockholm: SNS förlag, 2000.

Sjöstrand, Wilhelm. Pedagogikens historia III:2: Utvecklingen i Sverige under tiden 1805-1920. Lund: Gleerup, 1965.

Sörensen, Anna. Växelundervisningssällskapets normalskola och folkskoleseminariet i Stockholm 1830-1930. Stockholm: s.n., 1930.

- Svenska folkskolans historia: Del III. Det svenska folkundervisningsväsendet 1860-1900. Stockholm: Bonniers, 1942.

Tegborg, Lennart. Folkskolans sekularisering 1895-1909: Upplösning av det administrativa sambandet mellan folkskola och kyrka i Sverige. Stockholm: Föreningen för svensk undervisningshistoria, 1969.

Thunander, Gunnar. Fattigskola - medborgarskola: Studier i den svenska folkskolans historia med särskild hänsyn till Malmö. Malmö: C.A. Andersson, 1946. 
Tröhler, Daniel. "Curriculum History or the Educational Construction of Europe in the Long Nineteenth Century." European Educational Research Journal 15, no. 3 (2016): 279-97.

Wallin, Bodil. "Att forma en skolform: Svensk folkskolepolitik vid mitten av 1800-talet." In Ideologi och socialpolitik i 1800-talets Sverige: Fyra studier, edited by Ingrid Hammarström, Väinö Helgesson, Barbro Hedvall, Christer Knuthammar, and Bodil Wallin, 375-408. Stockholm: Almqvist \& Wiksell International, 1978.

Wallner, Johan. Folkskolans organisation och förvaltning i Sverige under perioden 1842-1861. Lund: s.n., 1938.

Warne, Albin. Om tillkomsten av vår första folkskolestadga. Stockholm: Föreningen för svensk undervisningshistoria, 1961.

Wennås, Olof. "Ideér och intressen i folkskolefrågan 1809-1840." In Utbildningshistoria 1992, edited by Egil Johansson and Stig G. Nordström, 41-62. Uppsala, 1992.

Westberg, Johannes. “'Freedom for All! Injustice for None!' The Peasant Estate and the Funding of Elementary Schools in Rural Sweden, 1840-41.” In Erziehung Und Bildung in Ländlichen Regionen - Rural Education, edited by Claudia Gerdenitsch and Johanna Hopfner, 219-29. Frankfurt am Main: Peter Lang, 2011.

—. Att bygga ett skolväsende: Folkskolans förutsättningar och framväxt 1840-1900. Lund: Nordic Academic Press, 2014.

- Funding the Rise of Mass Schooling: The Social, Economic and Cultural History of School Finance in Sweden, 1840-1900. Cham: Palgrave Macmillan, 2017.

—. "A Conflicted Political Will to Levy Local Taxes: Inequality and Local School Politics in Sweden, 1840-1900.” Nordic Journal of Studies in Educational Policy 4, no. 1 (2018): 3-12.

- "How Did Teachers Make a Living? The Teacher Occupation, Livelihood Diversification and the Rise of Mass Schooling in NineteenthCentury Sweden." History of Education 48, no. 1 (2019): 19-40. 
Open Access This chapter is licensed under the terms of the Creative Commons Attribution 4.0 International License (http://creativecommons. org/licenses/by/4.0/), which permits use, sharing, adaptation, distribution and reproduction in any medium or format, as long as you give appropriate credit to the original author(s) and the source, provide a link to the Creative Commons license and indicate if changes were made.

The images or other third party material in this chapter are included in the chapter's Creative Commons license, unless indicated otherwise in a credit line to the material. If material is not included in the chapter's Creative Commons license and your intended use is not permitted by statutory regulation or exceeds the permitted use, you will need to obtain permission directly from the copyright holder. 